\title{
Quest for the Lost World, or palaeontological geotourism
}

\section{W poszukiwaniu zaginionego świata, czyli geoturystyka paleontologiczna}

\author{
Maria Andruszkiewicz-Gorzelak ${ }^{1}$, Włodzimierz Mizerski \\ ${ }^{1,2}$ Polish Geological Institute - National Research Institute, ul. Rakowiecka 4, 00-975 Warszawa, Poland \\ ${ }^{1}$ maria.andruszkiewicz-gorzelak@pgi.gov.pl, ${ }^{2}$ wlodzimierz.mizerski@pgi.gov.pl
}

\section{* Corresponding Author}
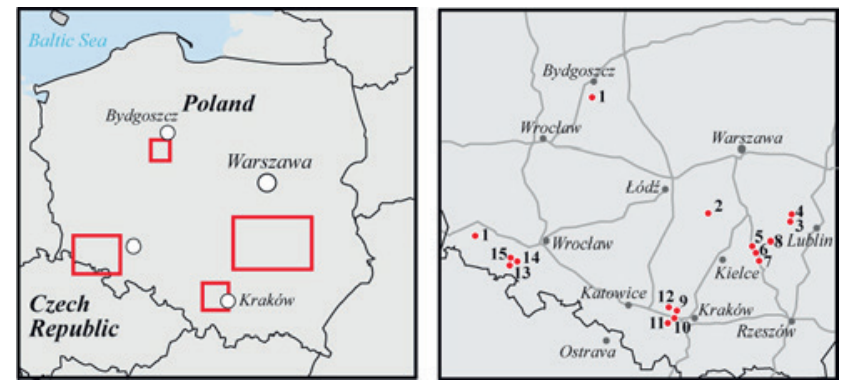

Article history:

Received: 6 June 2017

Accepted: 7 May 2018

Available online: 28 July 2018

(C) 2017 Authors. This is an open access publication, which can be used, distributed and reproduced in any medium according to the Creative Commons CC-BY 4.0 License requiring that the original work has been properly cited.

\begin{abstract}
Palaeontological geotourism could be one of many forms of propagating geological values of a country. It can meet the expectations of many tourists. For this broad category of people, paleontological tourism can instill curiosity about the extinct world, offering them places where they can feel like explorers, visiting these sites with a hammer and a chisel. Many of them will cherish the memories of adventures made during the search in the future, and some will find a new passion. Similar practices are used in Germany, for example, in Solnhofen or Holzmaden, where fossil exploration is available for a small fee. In most regions of Poland, you can find numerous places with fossils that anyone can search for. The greatest number of such sites can be found in the south of Poland, in the uplands and mountains, but also at the seaside, where the practice of palaeontological geotourism is possible. In the Holy Cross Mountains, the Sudetes, or in the Silesian-Cracow region, there are places where one finds fossils of plants or animals, including trace fossils. The only effort required in addition to the search for fossils is to develop guidelines and prepare guides for amateurs that quest for the lost world.
\end{abstract}

Key words: geotourism, geology, palaeontology, fossils

Treść: Geoturystyka paleontologiczna może być jedna z form propagowania walorów geologicznych kraju. Może spetnić oczekiwania wielu turystów. Wiele osób można zainteresować wymarlym światem, umożliwiając im zwiedzanie miejsc, gdzie moga poczuć sięak odkrywcy, odwiedzając je z młotkiem i dtutem. Część z nich będzie w przyszłości pielęgnować wspomnienia o przygodach w trakcie poszukiwań, a niektórzy odnajda swoja pasję. Podobne praktyki stosuje się np. w Niemczech - w Solnhofen czy Holzmaden, gdzie za drobna oplata można poszukiwać skamieniałości. W większości regionów Polski można znaleźć liczne miejsca ze skamieniałościami, których poszukiwać może każdy. Najwięcej takich stanowisk spotkamy na poludniu Polski, w strefach wyżyn i gór, ale i nad morzem uprawianie paleontologicznej geoturystyki jest możliwe. W Górach Świętokrzyskich, Sudetach czy rejonie śląsko-krakowskim sq miejsca, w których znajdziemy skamieniałości roślin lub zwierząt, a także same skamieniałości śladowe. Wymaga to jedynie wysiłku opracowania wskazówek i przewodników dla amatorów poszukiwań zaginionego świata.

Slowa kluczowe: geoturystyka, geologia, paleontologia, skamieniałości

\section{Introduction}

Among the wider population, and especially among the younger generation, there is a section of geology that is of particular interest, and which is neglected by geology popularisers. This section is palaeontology, more specifically the search for fossils. Several decades ago, geological guides for tourists were published, containing lots of information 
about fossils findable in rocks of the region described. Today, such publications are very rare, and they are hardly accessible for tourists (Mizerski, 1994; Machalski \& Stolarski, 2000; Mizerski et al., 2017). Information about fossils can be found in some scientific publications (Dzik, 2011; Mizerski \& Orłowski, 2017) or popular-science periodicals. However, they contain little exact information about the location of particular fossils. In libraries, one can still get the geological guides published in the 1960s and the 1970s for different regions of Poland, but currently they are practically unavailable (e.g. Kotański, 1968; Gradziński, 1972; Grocholski, 1969). Therefore, the proposal to extend the promotion of geotourism onto the problem of fossils occurring in rocks could widely reach the expectations of many tourists and receive a broad response. Certainly, there are collectors and enthusiasts who know what to search for and where to search. However, there is a broader group of people with curiosity about the extinct world, not only about the dinosaurs, for whom it could be useful to indicate the places to visit with a hammer and a chisel, where they can feel like explorers and discoverers. Certainly, many of them will cherish the memories of adventures during the search, and some of them will discover a new passion in it.

This article is not dedicated for geologists, but rather for tourists, organizers of tourism and teachers not based in Poland. The authors think that this form of geotourism will be interesting for many people. Geotourism is appreciated currently as very significant not only in Poland, but in other countries as well (for example Bruno et al., 2014; Henriques \& Penna dos Reis, 2015).

Many regions of Poland abound in places with fossils that anyone can see. The greatest number of such sites can be found in the south of Poland, in the uplands and mountains, but the search for fossils is possible also at the seaside. Obviously, it is not necessary to collect everything. In the Holy Cross Mountains, on the Sudetes, and in the Silesian-Cracow region, it is possible to recommend places where only plant fossils, only animal fossils, or even localities with only trilobites, cephalopods or trace fossils etc. can be found. This just requires developing relevant guidelines and guides for amateurs searching for the lost world.

It is obvious that any collection of fossils must be legal. In Poland, gathering of fossils for private collection is permitted. In any case, however, we must sensitize tourists to protect geological objects from which fossil retrieval is forbidden. The aim of the authors is not to present the whole wealth of fossils collectible in Poland, but to show that they can be a good aid in the development of geotourism in a region. After all, JuraPark in Bałtów was created thanks to the imagination of some people who believed that the fossils of the region would bring tangible benefits to it.

\section{Fossils}

To illustrate the possibilities of fossil gathering in several regions of Poland, let us look at some suggestions for one-day palaeontological tours. In the following article, selected paleontological sites from the north of Poland, through Central Poland, to the south are described. Discussed points in this article are located on the schematic map of Poland (Fig. 1).

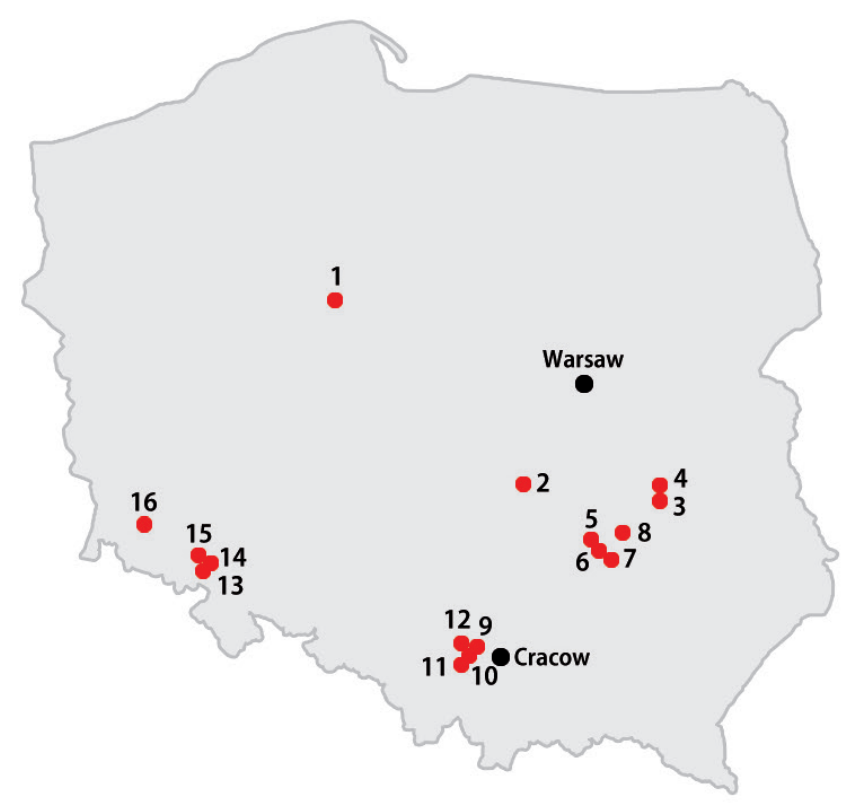

Fig. 1. Location in Poland of the discussed point in the text: 1 - Wapienno/Bielawa; 2 - Owadów Brzezinki; 3 - Kazimierz Dolny; 3 - Nasiłów; 5 - Doły Opacie; 6 - Bukowie; 7 - Gromadzice; 8 - Bałtów; 9 - Krzeszowice; 10 - Zalas; 11 - Kwaczała; 12 - Karniowice; 13 - Pogorzały; 14 - Lake Daisy; 15 - Lubiechów; 16 - Radłówka

On the Baltic Sea shores, fossils can be found directly on the beach. They occur in the rocks brought during the Pleistocene by the ice sheet from the Scandinavian Peninsula and from the Baltic Sea floor. They come from different geological periods, because the ice sheet carried fragments of rocks of different ages. These are mainly invertebrates that usually inhabited shallow seas. On the Polish beaches, we will find nautiloids, corals, sponges, brachiopods, gastropods, bivalves, sea urchins, crinoids, graptolites and even trilobites and belemnites.

Heading southward from the Baltic Sea, we reach the Kujawy region with the villages of Wapienno and Bielawa, between Inowrocław and Żnin (Fig. 1 - point 1). In this area, there is the largest limestone mine in Poland and one of the largest in Europe. In the Wapienno/Bielawa quarry, as many as 14 lithostratigraphic units have been identified in the formation rank, distinguishing 12 different lithologies containing very diverse fossils (Matyja \& Wierzbowski, 1981; Matyja 
et al., 1985). Exploitation of rocks is carried out in the Upper Jurassic (Oxfordian) limestones, offering numerous fossils, among others, starfish (Sphaeraster), stalked (Cyclocrinus) and free-living (Semiometra) crinoids, echinoderms (Rhabdocidaris (Fig. 2) and Plegiocidaris), polychaetes (Pannoserpula) and numerous ammonites, brachiopods and sponges (Radwańska, 2007). Because it is an active quarry, we must get permission if we want to enter its area and look for fossils.

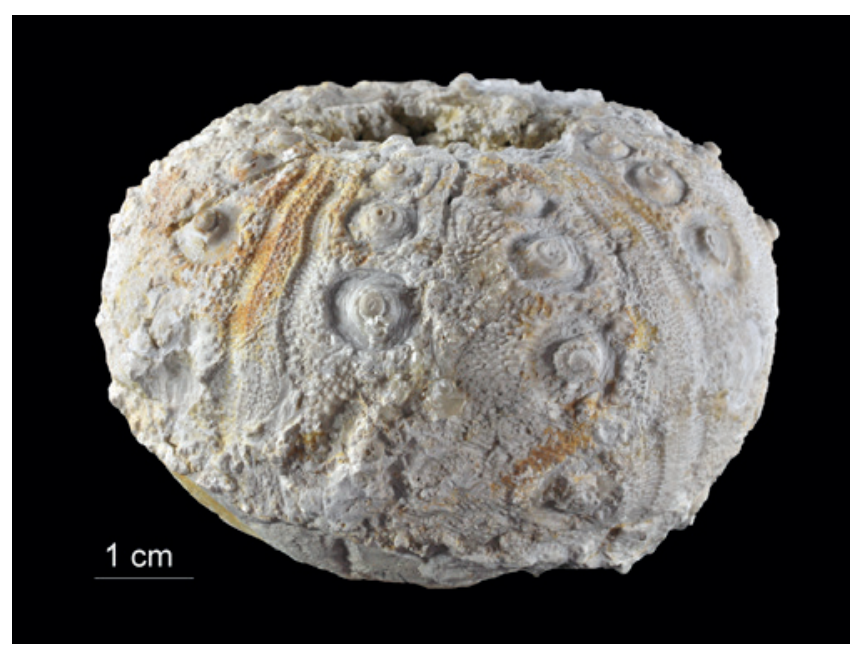

Fig. 2. Echinoid of the genus Rhabdocidaris, Upper Jurassic, Oxfordian (coll. Geological Museum PGI-NRI of Warsaw), photo K. Skurczyńska-Garwolińska

Eighteen kilometers southeast of Tomaszów Mazowiecki is the Owadów-Brzezinki quarry in Sławno near Opoczno, where Upper Jurassic (Tithonian) limestones are exposed (Fig. 1 - point 2). This is a unique site called the "Polish Solnhofen", where you can find very well-preserved fossils of marine and terrestrial organisms (Kin \& Błażejowski, 2012) (Solnhofen - the most famous palaeontological site of Fossillagerstätte, i.e. a sedimentary deposit of fossils with exceptional preservation, providing valuable palaeontological data, located in southern Germany). In the Owadów-Brzezinki quarry, the most abundant fossils are bivalves of the species Corbulomima obscura, and slightly less numerous representatives of the genus Mesosaccella. There is also a wide range of cartilaginous and ray-finned fish, lobsters, shrimp and crabs (two new species of Limulus darwini and Crenatolimulus sp. nov. - the latter undescribed yet). We can also find there rare ammonites, remains of small sea reptiles and flying pterosaurs, as well as dragonflies and beetles (Kin \& Błażejowski, 2012).

The carbonate rocks exposed in this quarry are assigned to three complexes (Kin \& Błażejowski, 2012). The lowermost complex I is represented by limestones with numerous ammonites of the species Zaraiskites zarajskensis. These deposits were accumulated in a moderately deep-water environment. Complex II is represented by very shallow-marine platy limestones containing abundant sedentary polychaetes (Sedentarida). The uppermost exposed rocks are lagoonal deposits of complex III, containing an exceptionally rich accumulation of abundant and diverse marine and terrestrial faunas - the socalled corbulomina horizon (the name comes from numerous bivalves of the genus Corbulomina). We must have permission to enter the Owadów-Brzezinki quarry area and look for fossils.

Heading east from Sławno, we reach Kazimierz Dolny nad Wisłą (Fig. 1 - point 3). South of the town centre, upon the Vistula River, is an abandoned quarry of Upper Cretaceous rocks. The siliceous marls (opoka) and limestones offer an abundance of fossils (Machalski, 1998). The most numerous among them are molluscs, including frequent cephalopods. The rocks contain belemnites represented predominantly by the genera Belemnitella and Belemnella, and ammonites of the genera Hoploscaphites, Discoscaphites, Baculites and Sphenodiscus. Bivalve fossils are also numerous - the most frequent are representatives of Ostrea, Pholadomya and Lyropecten (Pożaryska \& Pożaryski, 1951; Błaszkiewicz, 1980). Among gastropods, the dominant genera are Turritella and Aporrhais. There are also fossils of sponges, brachiopods, remains, and even entire branchlets of coniferous plants and shark teeth.

It is also worth to go to the quarry in Kamienny Dó in Kazimierz Dolny, where one can find grey-green gaizes with bulbous layers of hard limestones, representing the Paleocene (lowermost Cenozoic). These rocks bear a regional name of "siwak". Remains of a Paleocene crocodile from the genus Thoracosaurus (Żarski et al., 1998) were discovered in the rocks in 1995 (Fig. 3). It is the first such finding in Poland and the fourth in Europe. The skeleton fragment is part of the tail, including the thoracic and sacrum bones, and armour plates. Analysis showed that the sea in which the crocodile lived was no more than $80 \mathrm{~m}$ deep, and its waters had a temperature of about 18 degrees and salinity typical of open seas. Currently, this specimen is stored at the Geological Museum of the Polish Geological Institute in Warsaw.

When in Kazimierz Dolny nad Wisłą, it is worth taking a ferry to the other bank of the Vistula River to visit the Nasiłów quarry (Fig. 1 - point 4). This area is composed of rocks similar to those observed in Kazimierz - predominantly light-coloured, grey-yellow thick-bedded opokas with marl interbeds, and light grey gaizes with interbeds of limestones. They are Paleocene in age and overlie the Cretaceous rocks. These rocks contain abundant fossils (Machalski, 1998). The opokas host frequent ammonites of the genera Hoploscaphites and Baculites, nautiloids of the genera Eutrephoceras and Cymatoceras, and belemnites of the genus Belemnella (Fig. 4). We can find well-preserved sponges and bivalves, among others, of the genus Pholadomya. If we are lucky, we also find teeth of large predatory mosasaur reptiles and shark teeth (Abdel-Gawad, 1986; Machalski, 1998). 


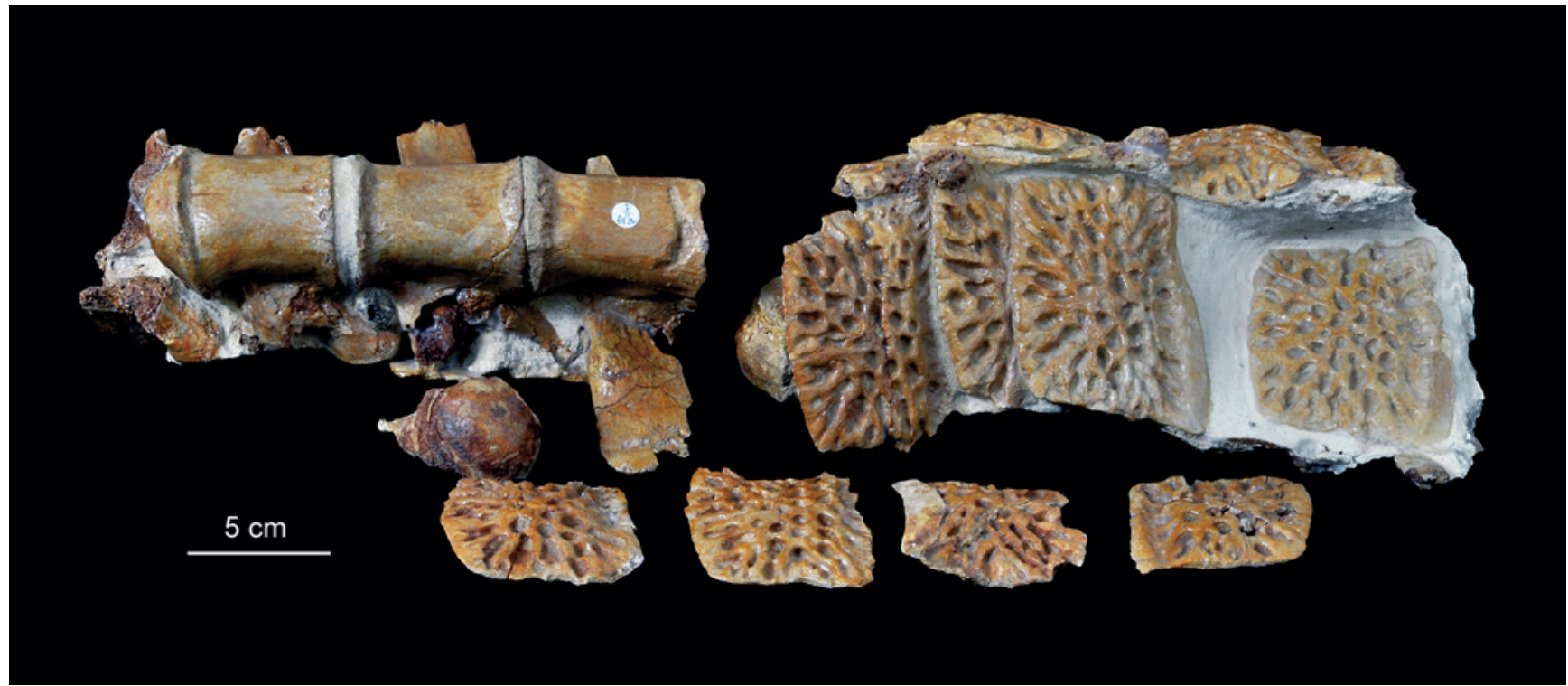

Fig. 3. Skeletons elements of Thoracosaurus, Paleocene (coll. Geological Muzeum PGI-NRI of Warsaw), photo K. Skurczuńska-Garwolińska

Southwest of Nasiłów, we encounter a real "fossil basin" which is the Holy Cross region. Among the many areas abounding in fossils, we are going to be acquainted with only one - the environs of Ostrowiec Świętokrzyski. In the Nietulisko area, northwest of Ostrowiec, there are numerous borrow pits, where Lower Triassic sandstones have been mined for a long time. In the Doły Opacie quarry (Fig. 1 - point 5), we can even notice that these rocks overlie Devonian dolomites exhibiting a disconformity. Lower Triassic sandstones of this area are represented by several rock complexes, including the Labyrinthodont Beds that contain bones of amphibians - labyrinthodontes, as well as footprints of reptiles called Isochirotherium and Chirotherium (Ptaszyński, 1996, 2000). We can imagine that lots of animals lived around an inland water body in this area, and its soft, muddy and flat shores favoured the preservation of footprints of these animals. It is worth mentioning, that the fossil tracks of Mesozoic reptiles were the main reasons for the creation of legends of evil paws and diabolical stones. In the cherry-coloured calcareous sandstones, which occur as interbeds, you can also find Gervillia mollusc fossils and, sometimes, fossil fish scales and bones.

Among interesting places in this region, with Middle Triassic rocks exposed on the surface, is a gorge at Bukowie, south of Kunów (Fig. 1 - point 6). The marls and limestones host a very wide range of fossils. Cephalopods are represented by nautiloids of the genus Germanonautilus, and ammonites of the genus Ceratites (Fig. 5). There are plenty of bivalves, i.a., of the genera Costatoria, Entolium and Lima, Coenothyris brachiopods, and Encrinus crinoids. Sometimes, it is possible to encounter fragments of skeletons of marine reptiles of the genus Nothosaurus.

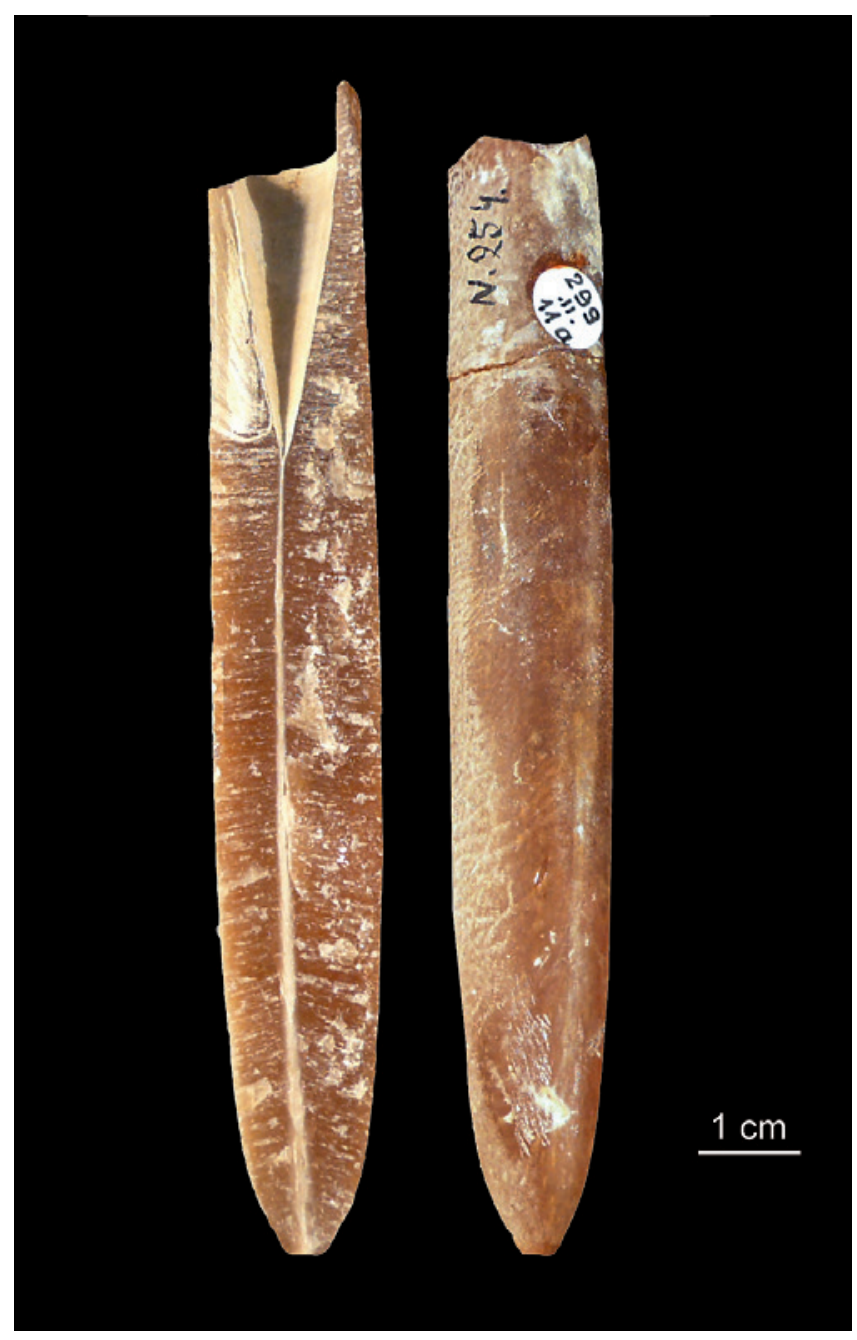

Fig. 4. Belemnite of the genus Belemnella, Upper Cretaceous, Maastrichtian (coll. Geological Muzeum PGI-NRI of Warsaw), photo K. Skurczuńska-Garwolińska 


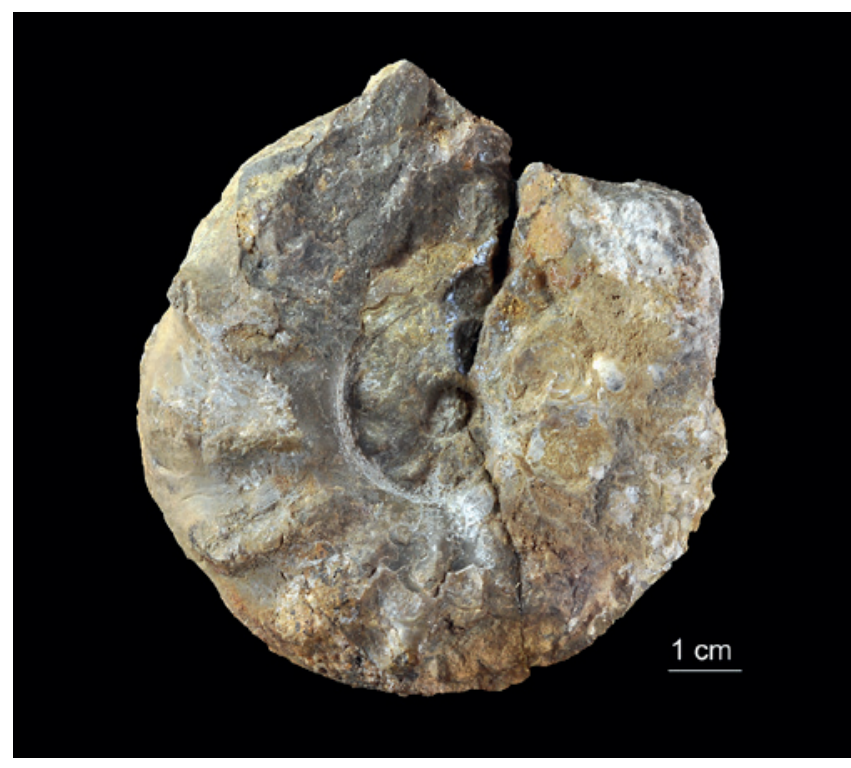

Fig. 5. Ammonite of the genus Ceratites, Middle Triassic, Muschelkalk (coll. Geological Muzeum PGI-NRI of Warsaw), photo K. Skurczyńska-Garwolińska

It is also worth visiting the valley of the Kamionka River, near the village of Gromadzice to the south of Ostrowiec Świętyokrzyski (Fig. 1 - point 7), where Lower Jurassic rocks outcrop. The best exposures are situated on the eastern slope of the valley, north of the village. This site is called Las Godziny by the locals. The valley scarp and numerous pits expose sandstones and siltstones that accumulated initially in fluvial and lacustrine environments and later in deltaic and nearshore settings. The rocks contain en masse occurrences of flora remains. About 50 plant species were described from them already almost 100 years ago. These are the Ginkgoaceae of the genera Ginkgo, Czekanowskia and Baiera, cycads of the genera Pterophyllum and Nilssonia, and pteridosperms of the genera Cladophlebis and Dictyophyllum (Makarewiczówna, 1928). Moreover, with good fortune, you can find footprints of several species of both predatory and herbivorous dinosaurs (Gierliński \& Pieńkowski, 1997) and, in the upper part of the section, marine bivalves of the genus Cardinia.

When exploring the Holy Cross region, it is worth visiting Bałtów (Fig. 1 - point 8), not only for its Jura Park known worldwide, but also for numerous exposures of Upper Jurassic rocks offering very abundant fossils. The well-bedded limestones contain ammonites of the genera Perisphinctes and Aspidoceras. Particularly numerous are bivalve fossils of the genera Trigonia, Modiola, Lopha, Plagiostoma, Astarte and Pholadomya (Fig. 6). There are also gastropod fossils of the genus Nerinea, brachiopods of the genus Terebratula, and sponges of the genus Laocaetis. Some exposures in this area reveal reefal limestones of the same age. About 20 species of colonial corals have been described from these rocks, including those of the genus Isastrea (Gutowski, 2004).

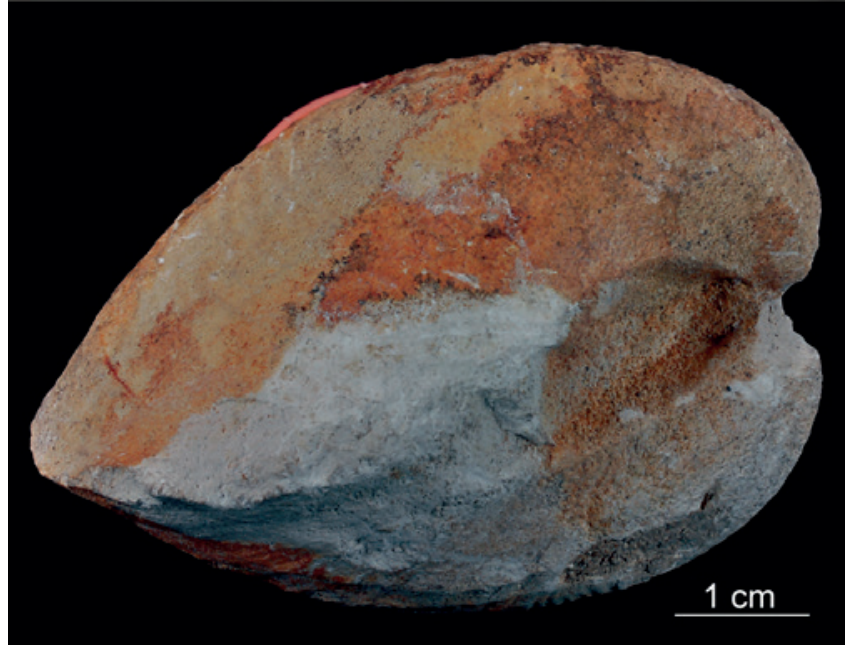

Fig. 6. Bivalve of the genus Pholadomya, Upper Jurassic, Oxfordian (coll. Geological Museum PGI-NRI of Warsaw), photo K. Skurczyńska-Garwolińska

From the Holy Cross region, we move to the Krzeszowice area (Fig. 1 - point 9) west of Cracow, where we encounter fossils originating from several geological periods. The beautifully located abandoned quarry in Dębnik and smaller pits usually overgrown with dense vegetation expose the black hard Dębnik Limestones of the upper Middle and lower Upper Devonian. Their intensive extraction started as early as the $16^{\text {th }}$ century, when Queen Bona brought Italian stone masters there. In Renaissance and Baroque times, "Marble Dębnik" was among the most valuable building materials used not only in Poland, but also in many other European countries. The limestones offer beautifully preserved fossils of stromatoporoid sponges of Amphipo$\mathrm{ra}$ and Stromatopora, tabulate corals of Macgeea and Alveolites, and brachiopods of Cyrtospirifer, Spinatrypa and Stringocephalus (Baliński, 1979).

The best sites for collecting the Lower Carboniferous fossils in the vicinity of Dębnik are in the valley of the small river of Eliaszówka. The limestones exposed, among others, in the Czatkowice quarry (entry permission required!) yield brachiopods of the genus Gigantoproductus (Fig. 7), tetracorals of the genus Zaphrentis, and stromatoporoids. We can also find trilobites, predominantly of the genera Phillipsia and Brachymetopus (Hoffmann \& Uchman, 2008).

South of Krzeszowice, in old pits on Czerwieniec Hill, there are calcareous sandstones containing numerous Middle Jurassic fossils. Here, we can find ammonites mainly of the genus Macrocephalites, bivalves of the genera Pholadomya, Pecten and Trigonia, gastropods of the genus Pleurotomaria (Fig. 8), and brachiopods - predominantly Rhynchonella and Terebratula (Giżejewska \& Wieczorek, 1976). 


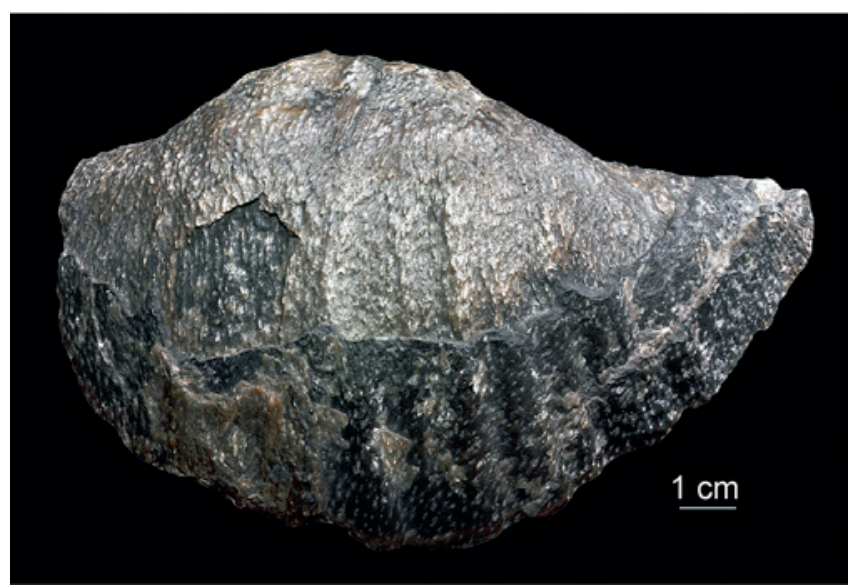

Fig. 7. Brachiopod of the genus Gigantoproductus, Carboniferous, Visean (coll. Geological Museum PGI-NRI of Warsaw), photo K. Skurczyńska-Garwolińska

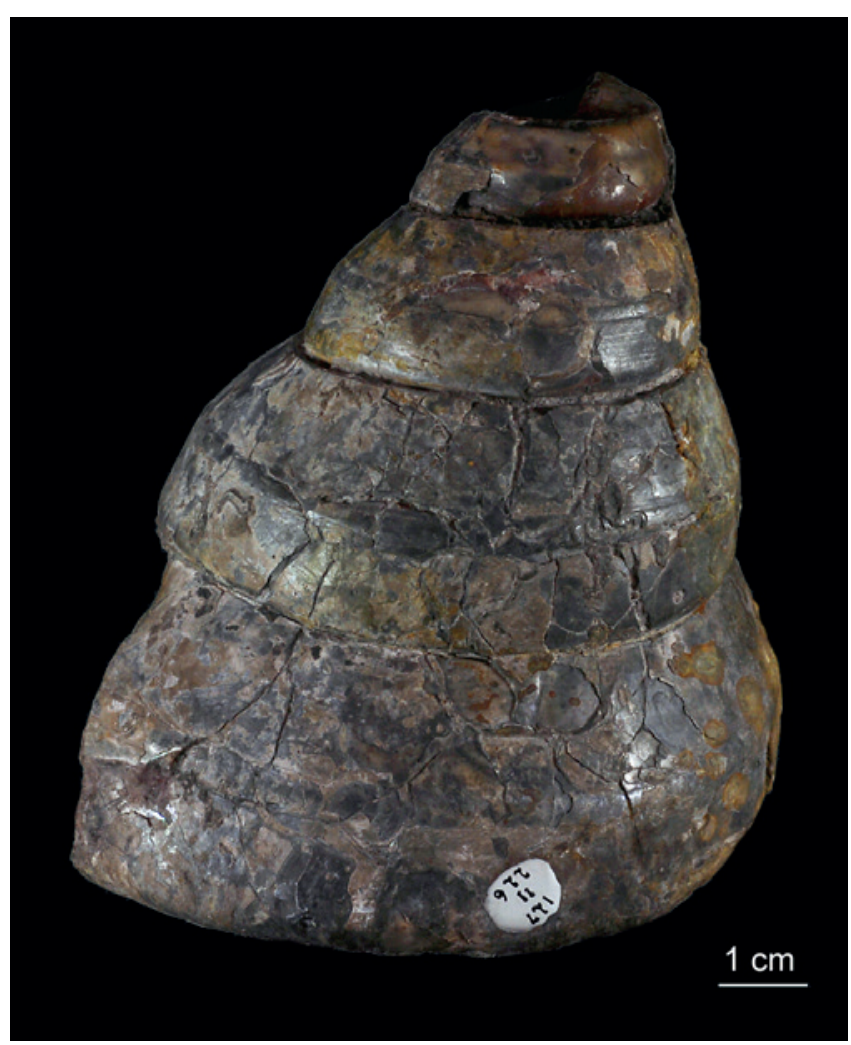

Fig. 8. Gastropod of the genus Pleurotomaria, Middle Jurassic, Bathonian (coll. Geological Museum PGI-NRI of Warsaw), photo K. Skurczyńska-Garwolińska

In the nearby village of Zalas (Fig. 1 - point 10 ), there is also a quarry exposing Middle Jurassic rocks. In the lower part, these are marine sands and less common quartz sandstones and conglomerates, containing well-preserved fossils of ammonites, including those of the genus Macrocephalites, and fragments of belemnites, bivalves, gastropods, echinoderms and corals of the genus Isastrea. The upper part of the section is composed of sandy crinoid limestones rich in fossil crinoids of the genera Balanocrinus and Cyclocrinus (Salamon \& Zatoń, 2006), bivalves, e.g. of the genus Ctenostreon, brachiopods of the genera Rhynchonella and Terebratula, and less frequent ammonites, belemnites and nautiloids (Giżejewska \& Wieczorek, 1976). In the Zalas quarry, there are also Upper Jurassic limestones that provide many other fossils. These are mostly ammonites, among others, of the genera Holcophylloceras, Sowerbyceras, Peltoceratoides, Perisphinctes (Fig. 9) and Cardioceras (Matyja \& Tarkowski, 1981).

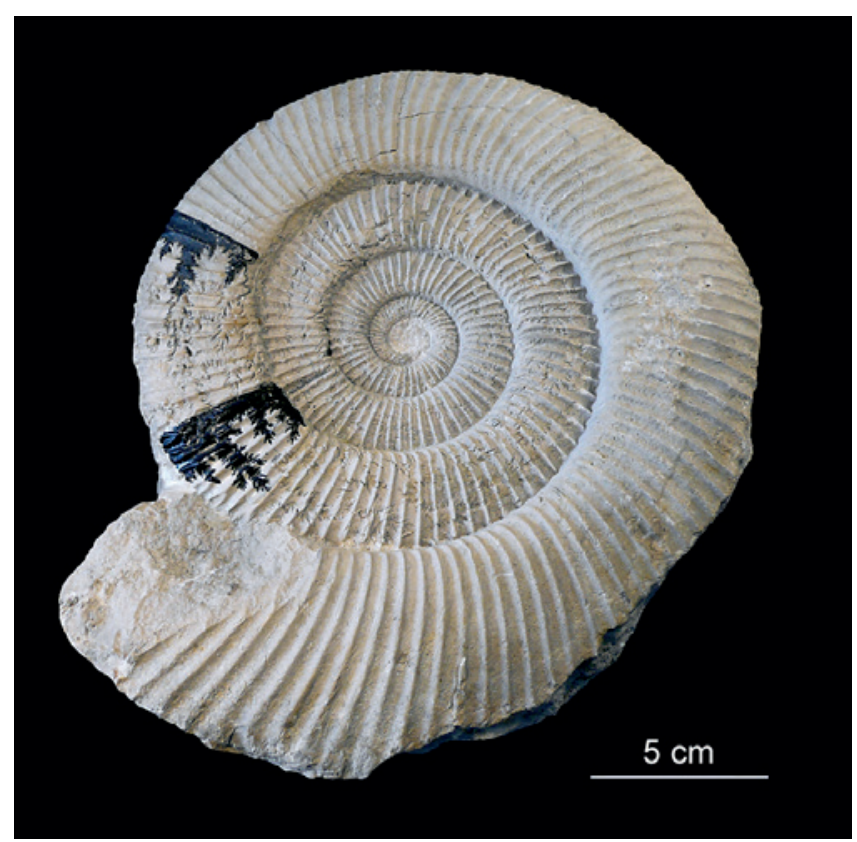

Fig. 9. Ammonite of the genus Perisphinctes, Upper Jurassic, Oxfordian (coll. Geological Museum PGI-NRI of Warsaw), photo K. Skurczyńska-Garwolińska

A few kilometres southwest, we can visit the village of Kwaczała near Alwernia (Fig. 1 - point 11). This trip can give us an idea of some Carboniferous plants. In the largest gorge, located north of the village, there are large exposures of rocks called the Kwaczała Arkose. These are sandstones, locally with large pebbles, which contain not only quartz, but also numerous feldspar and mica grains. Occasionally, they include thin interbeddings of clays. The Kwaczała Arkose contains fossil tree trunks of Araucaria of the genus Dadox$y$ lon, with the trunk diameter up to $1.2 \mathrm{~m}$ and length up to 7.5 m (Zastawniak, 2001; Stanisz \& Ziobro, 2013).

Between Krzeszowice and Chrzanów is the village of Karniowice (Fig. 1 - point 12), known for the Lower Permian travertines - the Karniowive Travertine (Ćwiżewicz \& Szulc, 1989). In an area of $6 \mathrm{~km}^{2}$, tors, abandoned quarries and pits overgrown with dense vegetation reveal 2-6-m thick 
beds of freshwater limestones. The travertine was discovered in 1870 by the Cracow botanist Marian Raciborski. It has a massive, porous structure and contains freshwater gastropods, among others of the genus Dendropupa, and imprints of plant leaves and stems, i.a., of the fern Sphenophyllum.

The lovers of fossils from Lower Silesia can also find some interesting things in the Sudetes. About $1.5 \mathrm{~km}$ northeast of Pogorzała (Fig. 1 - point 13), near Świebodzice, there are two exposures of conglomerates. Limestone pebbles composing the conglomerate contain Upper Devonian fossils. These are Tetracoralla of the genera Disphyllum, Macgeea and Marisastrum, and brachiopods (Fig. 10) of the genus Atrypa (Halamski, 2013). About $3 \mathrm{~km}$ to the northwest of these exposures there is a quarry of Upper Devonian reefal limestones, inactive for over 100 years now. The quarry bottom is occupied by a lake called Lake Daisy (Fig. 1 - point 14). This place is well known for its abundance of fossils that can be found in both the limestones and the interbedding mudstones and marls. These rocks contain goniatites of the genus Manticoceras, Tetracoralla of the genus Peneckiella, brachiopods of Schizophoria, Productella, Cyrtosipirifer (Fig. 11) and Pugnax, as well as bivalves, including those of the genus Buchiola (Gunia, 1962a).

If we go about $3.5 \mathrm{~km}$ further northwest from Lake Daisy to the village of Lubiechów (Fig. 1 - point 15), we find thick-bedded conglomerates exposed, including pebbles of Upper Devonian limestones that yield fossils, among others, of Alveolites tabulate corals and Amphipora stromatoporoids, as well as brachiopods (Fig. 12) of the genus Gypidula (Gunia, 1962b).

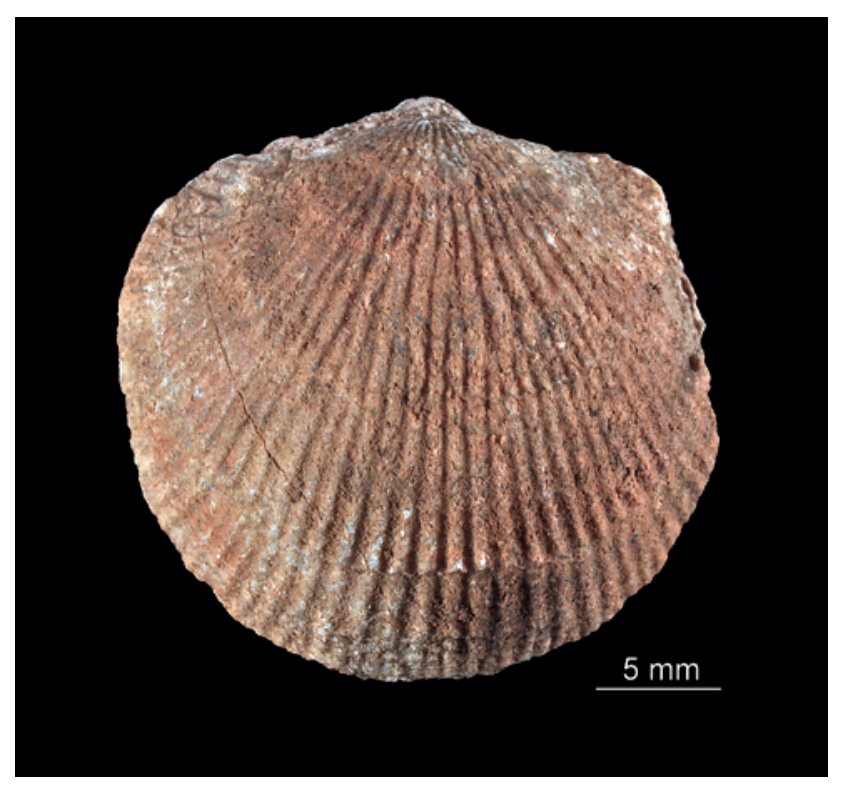

Fig. 10. Brachiopod of the genus Atrypa, Middle Devonian, Givetian (coll. Geological Museum PGI-NRI of Warsaw), photo K. Skurczyńska-Garwolińska

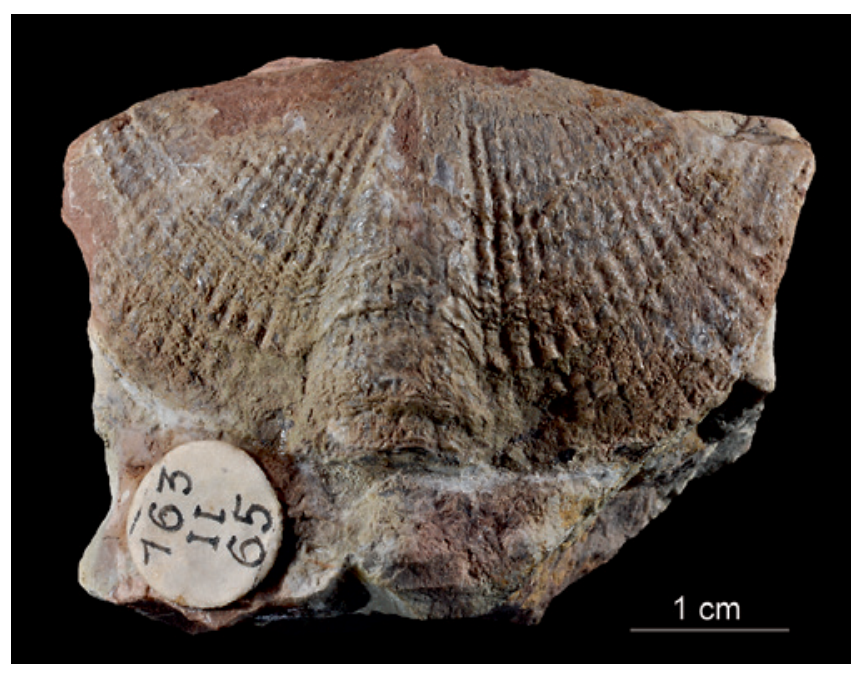

Fig. 11. Brachiopod of the genus Cyrtosipirifer, Upper Devonian, Famennian (coll. Geological Museum PGI-NRI of Warsaw), photo K. Skurczyńska-Garwolińska

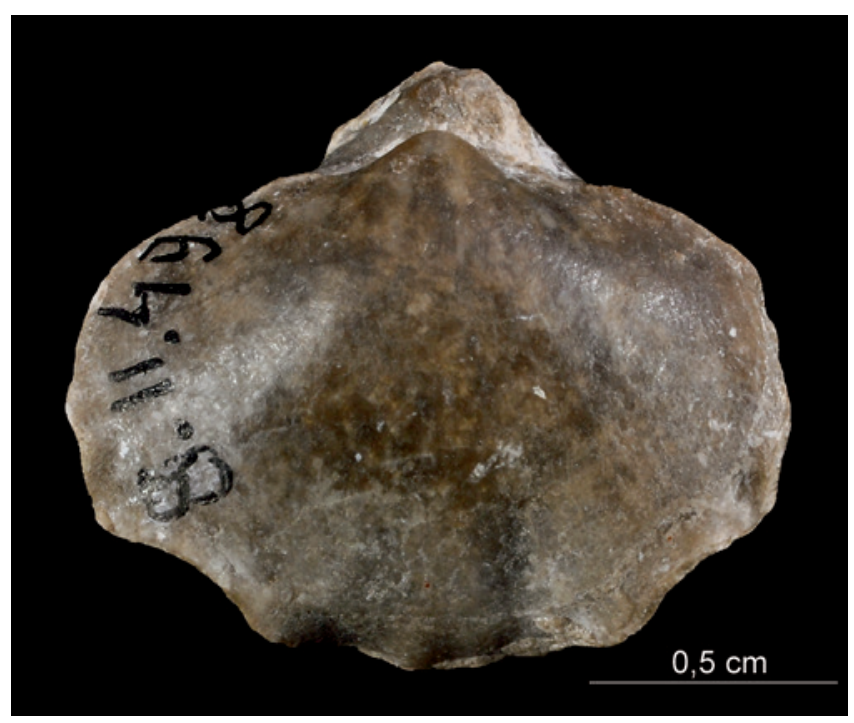

Fig. 12. Brachiopod of the genus Gypidula, Middle Devonian, Givetian (coll. Geological Museum PGI-NRI of Warsaw), photo K. Skurczyńska-Garwolińska

From the Świebodzice environs, we can move to the last region - in the vicinity of Lwówek Śląski (Fig. 1 - point 16). Several kilometres west of this town, near the village of Radłówka, there is a bushed quarry whose north-western edge approaches the road. The quarry exposes Upper Permian light grey thick-bedded limestones overlain by brownish sandy clay shales. In these rocks, it is possible to encounter fossil brachiopods of Productus, and bivalves, including the genera Schizodus and Pseudomonotis. If we are lucky, we can meet better- or worse-preserved imprints of fish representing the genus Palaeoniscus. In the village of Mojesz, located a few kilometres south of Lwówek Śląski, between 
specimens are a reason to be proud. However, treated this way they are decorative only, and we should try to find out more about them, especially about the environment of ancient geological epochs. Many fossils provide very clear indications of the distribution of ancient seas and lands. Based on an analogy to modern relatives of fossils of ancient organisms, we can first determine whether they are fossils of ancient marine or terrestrial organisms. Animals such as corals, brachiopods, cephalopods, echinoids or starfish today live only in the sea. Thus, in past geologic epochs, they lived in similar environments. Therefore, the presence of the fossils in the rock proves that it originated in the sea. Thus, in the place where land is today, there must have been a sea long ago. The study of plant fossils allows us to answer the question whether the land inhabited by these plants was a desert or a wetland, swampy area.

Most of deposits that we see on the continents originated in the seas and oceans. It is no wonder, since oceans covered most of our planet's surface. The nature of sedimentary basins is reconstructable, based on both characteristics of the deposits and their fossil content.

Fossils of marine organisms will help to answer the question of what the sea was like: shallow or deep, warm or cool: of normal salinity, brackish or highly saline? If we find many fossils of corals, we are sure that these animals lived in a warm and normally saline sea. If we find bryozoan fossils, then they surely prove that the sea water in which they lived must have been highly saline.

Here are other examples. In the beautiful gorge of „Prągowiec" located in the Holy Cross Mountains, we will find abundant fossils of extinct hemichordates - graptolites - in Silurian shales. The shales are full of fossils. Such a large amount of these planctic organisms indicates that the shales were deposited in an open-marine basin. However, if we meet a large number of colonial tabulate corals in Middle Devonian limestones in the Bolechowice quarry near Chęciny, we will be sure that the sea was not only warm, but also shallow, as colonial corals attach to the substrate and can live only in a zone of constant water movement (Bottjer, 2016).

Different marine organisms inhabit only shallow or only deeper parts of the sea. They live in colonies in shallow seas, and only single individuals dwell in deeper-marine areas. Organisms live different lifestyles: they inhabit the sea floor (benthos), actively swim (necton), or passively float in the water (plankton). Organisms living on the sea floor include those inhabiting only specified depth zones. Fossils of these organisms allow, in many cases, for a very precise determination of the environment in which the rocks of certain age were formed.

As mentioned above, fossils are not only organic remains, but also exhibit traces of their life activity (moving, feeding and dwelling) preserved in a fossilised state. The former are called structural fossils, and the latter are trace fossils or ichnofossils. Trace fossils, which tell us many things about the sedimentary environment, can be preserved on the surface of sediment layers or inside them. The sediment surface can reveal traces of creeping and crawling of organisms, known as organic hieroglyphs. Examples of such hieroglyphs are traces of trilobites - Palaeozoic marine arthropods. The most beautiful ones can be found in Poland in the active quarry of Wiśniówka Wielka near Kielce, where Cambrian sandstones are exploited. Trilobites (Fig. 13), crawling on the sea floor, lived in shelf (and thus shallow-water) seas. As such the conclusion that the rocks mined in the quarry, which are about 500 million years old, were deposited in a relatively shallow shelf sea, seems to be justified (Bottjer, 2016).

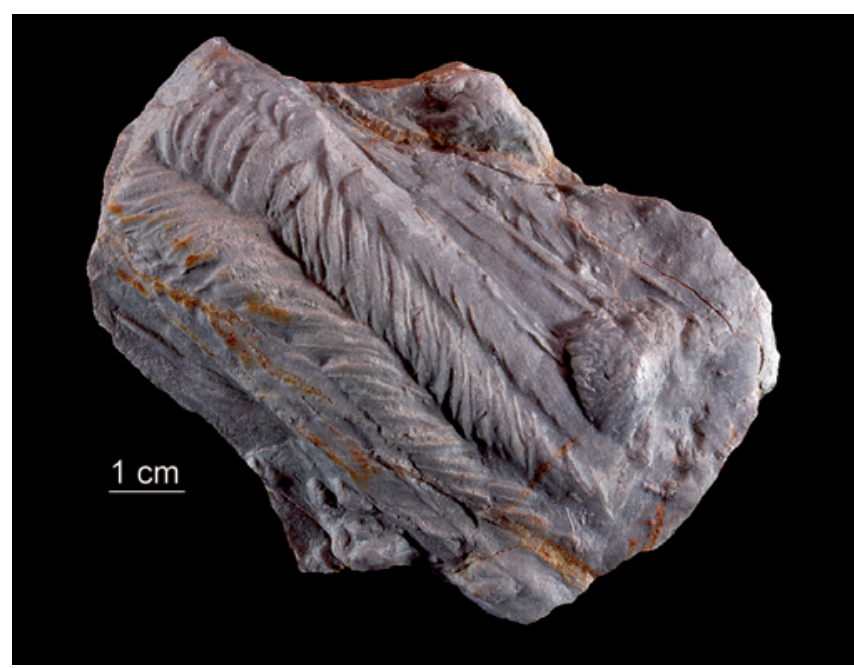

Fig. 13. Trackway of the Cambrian Trilobite (coll. Geological Museum PGI-NRI of Warsaw), photo K. Skurczyńska-Garwolińska

Traces of paws of vertebrates on bedding surfaces are called tracks. These can be found in many places of the Holy Cross region (e.g. in Doły Opacie, Sołtyków, Gliniany Las, Bałtów) in Triassic and Jurassic rocks, as well as in Tłumaczów, Lower Silesia, in Permian deposits. It is well known, that dinosaurs were terrestrial animals, but their tracks are sometimes found in limestones, which are marine sediments. Thus, we are going to draw the logical conclusion that, at those times when the track-forming dinosaurs lived, there must have been a very shallow sea with numerous shoals and flat islands barely rising above the sea level. The most famous, however, is the „Zachełmie” quarry near Zagnańsk north of Kielce, where tracks of the world's earliest tetrapods were discovered in Middle Devonian rocks (Niedźwiedzki et al., 2010). Another type of trace fossils are burrows produced in the sediment by various animals and the remains of borings in the rocky substrate by some bivalves, sponges or echinoids. They also point to a very shallow, nearshore marine environment during their life activity. 


\section{Palaeontological tourism in quarries and outcrops}

Most of its achievement palaeontology owes to arduous investigations and the quest for traces of the lost world. However, remarkable progress can sometimes occur by mere chance, or when someone completely unfamiliar with fossils inadvertently finds an unusual specimen that will later reach the hands of a paleontologist.

Our country is also not free from unexpected discoveries of great importance to palaeontology. Until recently, dinosaurs were known in Poland just by their tracks. Only the discoveries in the Krasiejów coal mine (Opole Silesia region) and in Lisowice allowed discovering bone remains of not only animals well known to science, but also pradinosaurs and their ancestors that are unknown to science (Dzik et al., 2000).

What can we say about the rather unexpected discovery of the tracks of the oldest tetrapods on Earth in the Holy Cross region? They had been known for some time, but no one knew what they were. Only studies of palaeontologists have shown that these are the traces of tetrapods that moved onto land earlier than Ichthyostega did, which was considered the oldest tetrapod. The same applies to the footprints of Jurassic dinosaurs, which had long waited for scientific interpretation, and had been considered "devil's feet" by the locals.

The rocks preserve a fraction of percent of representatives of the extinct world. Thus, a tourist interested in palaeontology can make an important discovery that may change or complement our knowledge of the organic world in the geological past. We have to encourage this.

Fossils cannot always be extracted from rocks in an easy fashion. If there is a problem with this, and the discovery appears valuable, it is better not to risk destroying it, but rather to notify a competent institution. We should not try to extract from hard rocks anything that can be of great importance to science, which may break into pieces, or crack at the blow of a rock hammer.

When entering the active quarry, permission from its management is always required, especially since the operation of some quarries is carried out using explosives. We should also remember to be particularly careful when penetrating active, abandoned and vertical walls of exposures. It is best to get a helmet in such cases.

Let us also remember that fossils cannot be collected without proper permission in areas of nature reserves, national parks and inanimate nature monuments. This is forbidden by law.

Unfortunately, the vast majority of fossils go through the hands of people who are unaware of the importance they may have for science. The number of miners, stonemasons and other people processing rocky material is far greater than the number of scientists studying life on Earth. Hence, many of the most important findings are often lost to science. We should try to prevent this by making everyone aware of the importance of fossils and of what they tell us about the history of the Earth.

At this point, we have to appeal to the Reader to remember that also he or she can contribute to the significant increase of our knowledge about the history of life on Earth by collecting fossils. It is important to pay attention to the fossils that are different from the "ordinary" and well-known forms in the rocks of a given age. We should try not to destroy them, but visit competent persons who will be able to evaluate their scientific value. Through this, we can become a participant in an important discovery and go down in history of science. It is of particular significance to search for the missing intermediate forms in the evolutionary chain. Secondary school students can ask for help from geography or biology teachers. There are also scientific centres in various cities, primarily higher education institutions, which have geological, geographic, biological or environmental protection departments. Appropriate departments in the Voivodeship Offices or Marshal Offices would also provide assistance. Finally, there are specialised scientific or museum centres, such as the Polish Geological Institute in Warsaw, which has six regional branch offices, the Institute of Palaeobiology of the Polish Academy of Sciences, the Institute of Geological Sciences PAS, or the Museum of the Earth PAS. Assistance would certainly be offered by regional museums in many cities. These may be the first step on the path to an important scientific discovery. Let us also remember that, according to geological and mining laws, important discoveries of fossils should be reported to the appropriate voivodeship authorities.

\section{Conclusions}

It seems that palaeontological tourism has a chance to become a more widely practiced type of geotourism. This is favoured by the presence of numerous fossil sites, by the easy access to many of them, and due to the natural desire, especially among young people, to unveil secrets. Palaeontological geotourism is certainly of great educational value, as it fosters the development of knowledge about the past of our country's land recorded in stone. Undoubtedly, it requires an increase in the amount of publications targeted to a wider audience, in which the tourist will find exhaustive information about where and what to search for to get into the mysterious past from millions of years before. This creates a huge role for researchers, especially palaeontologists, to bring the worlds of the past to all those interested. Such activity should certainly be as much appreciated as scientific activity. 


\section{References}

Abdel-Gawad G.I. 1986. Maastrichtian non-cephalopod mollusks (Scaphopoda, Gastropoda and Bivalvia) of the Middle Vistula Valley, Central Poland. Acta Geologica Polonica, 36: 1-3.

Balinski A., 1979. Brachiopods and Conodonts from the Frasnian of the Dębnik Anticline, sout-hern Poland. Palaeontologia Polonica, 39: 3-95.

Błaszkiewicz A., 1980. Campanian and Maastrichtian ammonites of the Middle Vistula Valley, Poland: a stratigraphic and palaeontological study. Prace Instytutu Geologicznego, 62: 3-63.

Bottjer D.J., 2016. Paleoecology: Past, Present, and Future. John Wiley $\&$ Sons, Ltd. Wiley Online Library.

Bruno D.E., Crowley B.E., Gutak J.M., Moroni A., Nazarenko O.V, Oheim K.B., Ruban D.A., Tiess G. \& Zorina S.O., 2014. Paleogeography as geological heritage: Developing geosite classification. Earth-Science Reviews, 138: 300-312.

Ćwiżewicz M. \& Szulc J., 1989. Warunki klimatyczne środowiska sedymentacji martwicy karniowickiej. Przeglad Geologiczny, 37: 180-186.

Dzik J., 2011. Dzieje życia na Ziemi. Wydawnictwo Naukowe PWN, Warszawa.

Dzik J., Sulej T., Kaim A. \& Niedźwiedzki R., 2000. Późnotriasowe cmentarzysko kręgowców lądowych w Krasiejowie na Śląsku Opolskim. Przegląd Geologiczny, 38: 226-235.

Gierliński G. \& Pieńkowski G., 1997. New finds of dinosaurs in Liassic in the Holy Cross Mountains and its palaeoinvernonmental Bacground. Przegląd Geologiczny, 35: 199-205.

Giżejewska M. \& Wieczorek J., 1976. Remarks on the Callovian and Lower Oxfordian of the Zalas area (Cracow Upland, Southern Poland). Bulletin de l'Académie Polonaise des Sciences. Série des Sciences de la Terre, 24: 167-175.

Gradziński R., 1972. Przewodnik geologiczny po okolicach Krakowa, Wydawnictwa Geologiczne, Warszawa.

Grocholski W., 1969. Przewodnik geologiczny po Sudetach. Wydawnictwa Geologiczne, Warszawa.

Gunia T., 1962a. Fauna, stratygrafia i warunki sedymentacji górnego dewonu depresji Świebodzic. Geologia Sudetica, 4: 115-220.

Gunia T., 1962b. Fauna otoczaków wapieni a zagadnienie wieku zlepieńców z Witoszowa (Dolny Śląsk). Rocznik Polskiego Towarzystwa Geologicznego, 32: 493-523.

Gutowski J., 2004. Dynamika rozwoju utworów koralowych środkowego oksfordu okolic Bałtowa. Volumina Jurassica, 2(2): 17-28.

Halamski A.T., 2013. Frasnian Atrypida (Brachiopoda) from Silesia (Poland) and the age of the eo-Variscan collision in the Sudetes. Geodiversitas, 35(2): 289-308.

Henriques M.H. \& Penna dos Reis R., 2015. Framing the Palaeontological Herritage Within the Geological Heritage: An Integrative Vision. Geoheritage, 7: 249-260.

Hoffmann M. \& Uchman A., 2008. Stop 2. Dębnik - the new quarry Devonian (Frasnian) limestones. In: Pieńkowski G. \& Uchman A. (eds), Ichnological Sites of Poland; The Holy Cross Mountains and the Carpathian Flysch, The Second International Congress on Ichnology, Cracow, Poland, August 29-September 8, 2008, Pre-Congress and Post-Congress Field Trip Guidebook. Polish Geological Institute, Warszawa: 144-152.
Kin A. \& Błażejowski B., 2012. Polskie Solnhofen. Przegląd Geologicz$n y$, 60: 375-379.

Klein H. \& Lucas S.G., 2010. Tetrapod footprints - their use in biostratigraphy and biochronology of the Triassic. Geological Society, London, Special Publications: 419-446.

Kotański Z., 1968. Z plecakiem i mtotkiem w Góry Świętokrzyskie. Wydawnictwa Geologiczne, Warszawa.

Machalski M. 1998. Granica kreda-trzeciorzęd w przełomie Wisły. Przeglad Geologiczny, 46(11): 1153-1161.

Machalski M. \& Stolarski, J., 2000. Paleofakty. Wydawnictwo RTV, Warszawa.

Makarewiczówna A., 1928. Flora dolno-liasowa okolic Ostrowca. Prace Towarzystwa Przyjaciót Nauk w Wilnie, 4: 1-49.

Matyja B.A., Merta T. \& Wierzbowski A., 1985. Stratygrafia i litologia utworów jurajskich struktury Zalesia. In: Kasztelanic T. (ed.), Utwory jurajskie struktury Zalesia na Kujawach i ich znaczenie surowcowe: Wiktorowo październik 1985: 19-29.

Matyja B. \& Tarkowski R., 1981. Lower and Middle Oxfordian ammonite biostratigraphy at Zalas in the Cracow Upland. Acta Geologica Polonica, 31: 1-14.

Matyja B. \& Wierzbowski A., 1981. Stratygrafia i pozycja facjalna osadów górnojurajskich okolic Barcina i Piechcina na tle obszarów przyległych. Geological Quarterly, 25: 513-526.

Mizerski W., 1994. Na tropach zaginionego świata. Wydawnictwo FORTIS, Kraków.

Mizerski W. \& Orłowski S., 2017. Geologia historyczna. Wydawnictwo Naukowe PWN, Warszawa.

Mizerski W., Skurczyńska-Garwolińska K. \& Olczak-Dusseldorp K., 2017. Nie tylko dinozaury. Poradnik dla poszukiwaczy skamieniatości. Państwowy Instytut Geologiczny - Państwowy Instytut Badawczy, Warszawa.

Niedźwiedzki G., Szrek P., Narkiewicz K., Narkiewicz M. \& Ahlberg P.E., 2010. Tetrapod trackways from the early Middle Devonian period of Poland. Nature, 463: 43-48.

Pożaryska K. \& Pożaryski W., 1951. Przewodnik geologiczny po Kazimierzu i okolicy. Wydawnictwa Muzeum Ziemi, Warszawa.

Ptaszyński T. 1996. Ślady gadów w najniższym pstrym piaskowcu okolic Ostrowca Świętokrzyskiego. Przegląd Geologiczny, 44: 1042-1043.

Ptaszyński T. 2000. Lower Triassic vertebrate footprints from Wióry, Holy Cross Mountains, Poland. Acta Palaeontologica. Polonica, 45: 151-194.

Radwańska U., 2007. A rare comatulid crinoid, Semiometra petitclerci (CAILLET, 1923), from the Upper Oxfordian of Poland. Acta Geologica Polonica, 57(2): 161-167.

Salamon M.A. \& Zatoń M., 2006. Balanocrinus hessi n. sp., a new crinoid (Echinodermata) from the Callovian (Middle Jurassic) of southern Poland. Neues Jahrbuch für Geologie und Paläontologie - Abhandlungen, 240: 1-17.

Stanisz J. and Ziobro A., 2013. Arkose sandstone - a forgotten treasure of Kwaczała. Geotourism 1-2(32-33): 47-58.

Zastawniak E., 2001. Historia szaty roślinnej Krakowa i jego najbliższych okolic, Wiadomości Botaniczne, 45: 7-14.

Żarski M., Jakubowski G. \& Gawor-Biedowa E., 1998. The first Polish find of Lower Paleocene crocodile Thoracosaurus Leidy. 1852: geological and paleontological description. Geological Quarterly, 42(2): 141-160.

This paprer is extended versions of presentations delivered during the III Forum GEO-PRODUKT: „From geoeducation to innovation”, which was held on September, 22-24, 2017 in Wojsławice, Poland (Sudetic Foreland Geopark). For details, please, visit the webpage (http://geoprodukt2017.geopark.org.pl).

Niniejszy artykuł stanowi rozszerzenie referatu wygłoszonego w ramach III Forum GEO-PRODUKT: „Od geoedukacji do innowacji”, które odbyło się w dniach 22-24 września 2017 roku w Wojsławicach, Geopark Przedgórze Sudeckie (http://geoprodukt2017.geopark.org.pl). 